\title{
Environmental factors affecting larval fish community in the salt marsh area of Guadiana estuary (Algarve, Portugal)
}

\author{
Renata Gonçalves ${ }^{1,2}$, Ana Dulce Correia ${ }^{3,4}$, Natasa Atanasova ${ }^{5}$, Maria Alexandra Teodósio ${ }^{1,2}$, \\ Radhouan Ben-Hamadou ${ }^{6}$, Luís Chícharo ${ }^{1,5}$ \\ ${ }^{1}$ Universidade do Algarve, Faculdade de Ciências e Tecnologia, Campus de Gambelas, 8005-139 Faro, Portugal \\ ${ }^{2}$ CCMAR, Centro de Ciências do Mar, Campus de Gambelas, 8005-139 Faro, Portugal. E-mail: ecogoncalves@ gmail.com \\ ${ }^{3}$ Capel Manor College, Animal Care Department, Ledrington Road, London SE19 2BS. \\ ${ }^{4}$ ULHT Faculdade de Engenharia, Universidade Lusófona, Campo Grande, 376, 1749-094 Lisboa, Portugal \\ ${ }^{5}$ CIMA, Centro de Investigação Marinha e Ambiental. Campus de Gambelas, 8005-139 Faro, Portugal. \\ ${ }^{6}$ Department of Biological and Environmental Sciences, College of Arts and Sciences, Qatar University, \\ P.O. Box 2713, Doha, Qatar.
}

\begin{abstract}
Summary: Salt marsh areas in the Guadiana estuary are important nursery sites for many fish species of commercial and recreational value. More effective protection measures should be adopted as the area is highly affected by anthropogenic and natural threats. Studying larval fish communities in these impacted nursery areas will be relevant to the management of local ecosystems and to larval fish ecology in general. Spatial and seasonal distribution and the effect of environmental factors on the larval fish community of this ecosystem were studied for one year (April 2010 to March 2011). Larvae were sampled monthly in parallel with phytoplankton and zooplankton. Hydrological data and physical parameters were monitored. A decision tree model was used to assess the influence of environmental factors on the larval fish community. A total of 130 larvae and 1171 eggs were caught. Diplodus sargus, Sardina pilchardus, and Pomatoschistus microps were the most abundant larval fish species. The peaks of fish larvae abundance occurred in March and April. The output of the model demonstrates that the abundance of larval fish is determined by the abundance of eggs, zooplanktonic food, and water flood and flow. This study shows the importance of the Guadiana salt marsh as an area for fish nursery and highlights the need for conservation of this area.
\end{abstract}

Keywords: larval fish; salt marsh; Guadiana estuary; fish eggs; food availability; flooding events; river flow.

Factores ambientales que afectan a la comunidad de larvas de peces en las marismas del estuario del Guadiana (Algarve, Portugal)

Resumen: Las zonas de marisma en el estuario del Guadiana constituyen zonas de cría importantes para muchas especies de peces de valor comercial y recreativo. Deberían ser adoptadas unas medidas de protección más efectivas ya que el área está altamente afectada por amenazas tanto antropogénicas como naturales. El estudio de las comunidades de larvas de pez en estas áreas de cría más impactadas será relevante para la gestión del ecosistema local y para la ecología de las larvas de pez en general. La distribución espacial y estacional, y el efecto de factores ambientales en las comunidades de larvas de pez de este ecosistema fueron estudiados durante un año (abril de 2010- marzo de 2011). El muestreo de las larvas fue realizado mensualmente en paralelo con el de fitoplancton y zooplancton. También fueron monitoreados datos hidrológicos y parámetros físicos. Un modelo de Árbol de Decisión fue utilizado para evaluar la influencia de factores ambientales en la comunidad de larvas de pez. Fueron recogidos un total de 130 larvas y 1171 huevos. Diplodus sargus, Sardina pilchardus y Pomatoschistus microps fueron las especies más abundantes. Los picos de abundancia de larvas de pez ocurrieron en marzo y abril. Los resultados del modelo demuestran que la abundancia de larvas de pez viene determinada por la abundancia de huevos, la comida zooplanctónica, los eventos de inundación y el caudal del río. Este estudio muestra la importancia de las marismas del Guadiana como área de cría, y refleja la necesidad de conservar este área.

Palabras clave: larvas de peces; marismas; estuario del Guadiana; huevos de peces; disponibilidad de comida; eventos de inundación; caudal del río.

Citation/Como citar este artículo: Gonçalves R., Correia A.D., Atanasova N., Teodósio M.A., Ben-Hamadou R., Chícharo L. 2015. Environmental factors affecting larval fish community in the salt marsh area of Guadiana estuary (Algarve, Portugal). Sci. Mar. 79(1): 25-34. doi: http://dx.doi.org/10.3989/scimar.04081.08A

Editor: J. J. Govoni.

Received: April 24, 2014. Accepted: November 14, 2014. Published: January 13, 2015.

Copyright: () 2015 CSIC. This is an open-access article distributed under the Creative Commons Attribution-Non Commercial Lisence (by-nc) Spain 3.0. 


\section{INTRODUCTION}

The salt marsh area of the Guadiana estuary, namely the Castro Marim area, was awarded Natural Reserve status in 1975. It is a very important area for biodiversity conservation at regional, national and international levels. This importance is mainly related to the presence of wetlands and coastal ecosystems (e.g. salt marsh creeks) that house a diverse fish fauna. In particular the two main creeks-Lezíria and Carrasqueira - are important sites of reproduction for many fish species of commercial value (Beja et al. 2007). More effective protection measures should be adopted as the area is highly affected by: (1) water obstruction and river fragmentation upstream, (2) local recreation activities and navigation, (3) pollution from wastewater emissions, and (4) heavy tourism (Videira et al. 2008). River flow in the Guadiana basin is controlled by numerous dams, which shift the natural flow regime, decrease natural variability (Morais et al. 2009), and induce changes in habitat availability by increasing sand deposition in saltmarshes (Garel et al. 2009). This area is also affected by invasive species (Chícharo et al. 2009) with potential negative effects on ichthyoplankton communities (Pereira et al. 2014). Moreover, the Guadiana saltmarshes are located in an area under Mediterranean climate influence and are classified as highly sensitive to global change. Studying fish larval communities in these impacted nursery areas with multidisciplinary approaches based on a detailed understanding of biota responses will be relevant to the management of local ecosystems and to larval fish ecology in general.

One of the most important processes for the environmental distribution of fish is habitat selection, defined as the non-random use of space resulting from the voluntary movements of organisms (Kramer et al. 1997). Habitat selection by fish is a response to a multiple factors, including abiotic conditions (temperature, salinity, water velocity, climatic conditions) and biotic conditions (food resources, predation risk and competition). Because the responses of fish larvae to these factors change during ontogenic development, their relative importance for habitat selection is also dynamic (Craig and Crowder 2000). In particular, the survival and distribution of early life stages of fish is mainly dependent on the local hydrological conditions associated with transport processes, climatic variability, prey and predator densities, and adult spawning (Franco-Gordo et al. 2002).

Tidal salt marsh habitats are vegetated wetlands periodically flooded by tides and renowned for their high productivity (Kneib 1997). They include irregularly flooded marsh areas, intertidal marsh creeks, sub-tidal marsh creeks and the bay marsh fringe (Routree and Able 1996). Salt marshes are recognized as important nurseries and feeding grounds for many fish species (Kneib 1997). Despite the variability of the abiotic factors in marsh habitats, most estuarine and coastal fishes can tolerate a wide range of physical conditions. Abiotic factors are likely to influence the habitat selection of fish in more subtle ways via effects on energy demands rather than physiological tolerances (Craig and
Crowder 2000). In contrast, biotic factors, particularly food resources and predation risk, have a direct impact on the selection of these habitats by fishes. Also, there is evidence that salt marshes may be more profitable foraging areas than other habitats as they are a source of carbon, detritus, and primary/secondary production (Hettler 1989). Shallow and turbid waters associated with marshes also provide protection from predators during the critical life stages of fishes (Baltz et al. 1993).

The present study is the first to investigate the larval fish community in the Guadiana salt marsh area and the influence of environmental parameters on its occurrence. Veiga et al. (2006) analysed the Castro Marim salt marsh area in order to characterize communities of adult and juvenile fish. Other studies focusing on the population dynamics of fish larvae were only conducted in the main channel of the Guadiana estuary (Chícharo et al. 2000, Faria et al. 2006). This is a crucial first step for determining the sustainable carrying capacity of these ecosystems. We investigated spatial and temporal variations of the larval fish community in a salt marsh sub-tidal creek of the estuary and the effects of the environmental factors on larval fish occurrence using a decision tree (DT) model.

\section{MATERIALS AND METHODS}

\section{Study site}

The Castro Marim salt marsh is a 1222-ha wetland on the southeast coast of Portugal (latitude $37.12^{\circ} \mathrm{N}$; longitude $7.26^{\circ} \mathrm{W}$ ) near the mouth of the Guadiana River (Fig. 1). This system consists of tidal flats, intertidal creeks, saltworks, tidal pools, and two major sub-tidal creeks (Lezíria and Carrasqueira creeks) that cross the entire salt marsh and are inundated with every high tide. The two main creeks also have freshwater inflow that is greatest in winter. This ecosystem is characterized by semi-diurnal meso-tides (tidal range 1.22 to $2.82 \mathrm{~m}$ ) (Veiga et al. 2006). Typical halophytic vegetation (Zostera noltii, Spartina maritima, Puccinellia maritime, Arthrocnemu perenne, and Spartina densiflorae) covers the intertidal surface of the salt marsh, which is only completely inundated during high spring tides.

\section{Sampling strategy and field methodology}

Sampling was carried out monthly between April 2010 and March 2011 (except August 2010 due to logistical problems) at seven stations: six along one of the main sub-tidal creeks, Lezíria creek (stations 1 to 6, Fig. 1), and one at the mouth of the creek located in the main channel of the estuary (station 7, Fig. 1) and therefore under a high estuarine influence. A boat was used for all samplings. Accessibility and representativeness of the samples were the main factors influencing the choice of sampling stations. To minimize variations in environmental conditions between each sampling period and to standardize the sampling regime, all sampling was conducted at the beginning of the ebb tide. 


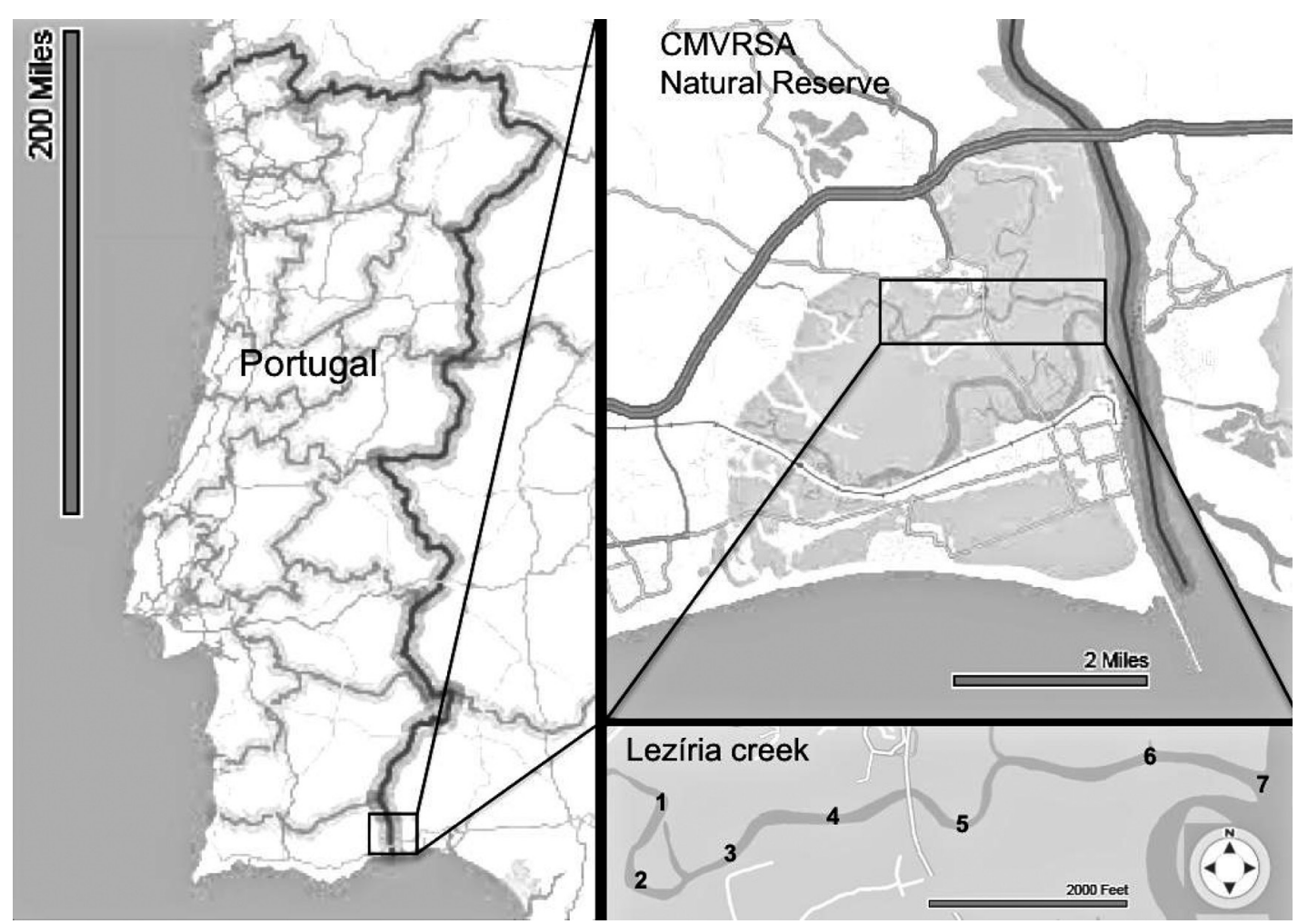

Fig. 1. - Locations of sampling stations along Lezíria creek in Castro Marim and Vila Real de Santo António Natural Reserve (RNCMVRSA), Portugal. Shaded area indicates the extent of the Natural Reserve.

To capture fish eggs and larvae, and their potential competitors and predators (meso- and macro-zooplankton), sub-surface ichthyoplankton trawls were carried out with a $48-\mathrm{cm}$ diameter plankton net with a 500- $\mu \mathrm{m}$ mesh, equipped with a Hydro-Bios flow meter to quantify the volume of water filtered $(34.6 \pm 7.7$ $\mathrm{m}^{3}$ per tow, mean $\left.\pm \mathrm{sd}\right)$. Collected samples were immediately preserved with $4 \%$ buffered formaldehyde. Water samples were collected from the surface for the analysis of dissolved inorganic macronutrients (ammonium, $\mathrm{NH}_{4}^{+}$; nitrate, $\mathrm{NO}_{3}^{-}$; nitrite, $\mathrm{NO}_{2}^{-}$; phosphate, $\mathrm{PO}_{4}{ }^{3-}$; and silicate, $\mathrm{SiO}_{4}{ }^{4-}$ ) and chlorophyll $a$. Samples were stored in 330-ml containers in the dark and at low temperature $\left(-18^{\circ} \mathrm{C}\right)$ until processing. Water samples for phytoplankton and micro-zooplankton analysis (potential prey for fish larvae) were also taken from the surface and were immediately fixed with acid Lugol's solution $0.003 \%$. Temperature, salinity, dissolved oxygen and $\mathrm{pH}$ were recorded at each station with a Yellow Springs Instruments (YSI Model 85) probe immersed $10-20 \mathrm{~cm}$ under the water surface. Turbidity was determined by Secchi disc. Daily river flow data and precipitation were obtained via the National Information System for Water Resources (SNIRH) web site (http://snirh.pt/snirh/_dadosbase/site).

\section{Laboratory analysis}

In the laboratory, fish eggs, larvae and the remaining preserved zooplankters were identified to the lowest possible taxa (Russell 1976 and Ré 1999) with a stereomicroscope (Leica S8AP0). Fish larvae were classified into the following ecological guilds, according to their biology and typical behaviour reported in the literature (Mathieson et al. 2000, França et al. 2009): estuarine residents (ER), which spend their entire lives in the salt marsh or estuary; marine seasonal migrants (MS), which migrate into the salt marsh or the estuary because of diet or reproductive needs; marine adventitious species (MA), which occur irregularly in salt marsh, and marine juvenile species (MJ), which spend the first stages of their life cycles in the salt marsh or estuary. Abundance of fish larvae and eggs was expressed as number of individuals /100 $\mathrm{m}^{3}$ (number of individuals / filtered water volume $\times$ $100)$, and meso- and macro-zooplanktons as number of individuals $\mathrm{m}^{-3}$ (number / filtered water volume). Phytoplankton and microzooplankton samples were transferred to sedimentation chambers (volume $=10$ $\mathrm{ml}$; sedimentation time $=24 \mathrm{~h}$ ) and observed at $200 \mathrm{x}$ magnification with an inverted microscope (Zeiss Axiovert S100). All plankton was counted in half of the visual fields and we assumed that the cells were randomly distributed.

Chlorophyll $a$ concentration was determined by filtering water samples through $0.7 \mathrm{~mm}$ pore filters (Whatman GF/F) without exceeding vacuum pressures of $100 \mathrm{mmHg}$. The filters were kept frozen until fluorimetric analysis (Knap et al. 1996).

To determine concentration of dissolved inorganic macronutrient, water samples were filtered through $0.45-\mu \mathrm{m}$ pore cellulose acetate filters (MSI) and preserved frozen $\left(-18^{\circ} \mathrm{C}\right)$ until being subjected to spectrophotometric analyses. All nutrients were determined in duplicate, according to the spectrophotometric methods described by Grasshoff et al. (1983), using 
a spectrophotometer (Hitachi U-2000) for phosphate and silicate and an auto analyser (Skalar Sansplus) for nitrate, nitrite and ammonia.

\section{Data analysis}

Non-parametric analysis of similarity (ANOSIM) and non-parametric multidimensional scaling (NMDS) were used to examine seasonal and spatial patterns of larval fish distribution and abundance according to the two established factors: "Season" (winter=January and February; spring=March, April and May; summer=June and July; autumn=September, October, November and December); and "Station" (from sampling station 1 to 7). The dissimilarity matrix constructed to perform these analyses was built after adding a dummy variable to deal with the high frequency of zeros in the dataset and setting Bray-Curtis distance as the similarity measure (Bray-Curtis distance ignores variables that have zeros [Quinn and Keough 2002]). ANOSIM analysis examines the existence of meaningful dissimilarities between established groups for each considered factor (Clarke and Warwick 2001). $R$ values equal to +1 indicates perfect separation between groups, in contrast to $R$ values equal 0 , which indicates no difference between groups (Quinn and Keough 2002). NMDS represents graphically relationships between objects in multidimensional space. The objects are represented on a plot with new variables as axes and the distance between the objects on the plot should represent their dissimilarity. The farther the objects are in the NMDS plot the larger the dissimilarity between them (Quinn and Keough 2002). Multivariate techniques (ANOSIM and NMDS) were applied using Primer 6.0 software (Primer-E Ltd).

Influence of environmental factors on ichthyoplankton abundance was investigated using DT analysis. The dataset, from which the DT is induced, is typically organized in a spreadsheet table, where each row corresponds to an example and each column to an attribute value of the example. Each example is composed of attributes (descriptors), and a class (also termed as a target or dependent variable). Herein, the attributes were 29 abiotic and biotic variables (Table 3 ) and the class was fish larvae. To apply DT analysis we discretesized the class variable fish larvae as "low", "medium" and "high" according to fish larvae abundance: $<2$ larvae $/ 100 \mathrm{~m}^{3} ; 2-10$ larvae $/ 100 \mathrm{~m}^{3}$; and $>10$ larvae $/ 100 \mathrm{~m}^{3}$. These categories for larvae abundance constituted the dependent variable. Through this categorization we aggregated several examples under same class and made the model induction more robust and reliable. Rules relating the low, medium and high abundance of fish larvae with biotic and abiotic conditions were created by means of single-target DT using the J48 algorithm part of the WEKA machine learning package (Witten et al. 2011). The algorithm repeatedly partitions the data set into subsets, as homogeneous as possible with respect to the target variable. Thus, the major task of the algorithm is to find the optimal splitting values of the measured attributes and to give the most accurate prediction of the target. The algorithm selects the most informative attributes, i.e. the attrib- utes according to which the splitting is performed, for the class variable (fish larvae in this case) based on information gain theory (IG) (Quinlan 1993, Witten et al. 2011) and puts them in a hierarchical tree-like structure (model) that is interpreted as IF THEN rules. The IG theory also deals with inter-related attributes. In cases of two correlated attributes, the IG is calculated for both of them (at each split) and the one that contributes more information is selected. Pruning is a valuable option embedded in $\mathrm{J} 48$, which results in different sizes of DTs depending on how the pruning parameters are set. Pruning improves the transparency of the induced trees by reducing their size, as well as enhancing their classification accuracy by eliminating errors that are present due to noise in the data. In our analysis, we applied the post-pruning option with a confidence factor of 0.25 and the forward-pruning by changing the minimal number of examples to a leaf parameter. By forcing a certain number of examples into a single leaf, this parameter cuts the least informative branches and makes the tree smaller and clearer. The latter was changed until we got a model of suitable size that satisfied the accuracy and interpretability criteria. A 10-fold cross-validation was used to validate the DT model. Cross-validation involves splitting the sample into a number of smaller groups. Trees are than generated with the data from each sub-sample excluded in turn. The predictive performance of the model was assessed on the basis of the percentage of correctly classified instances (CCI) and Cohen's kappa statistic (k). While CCI is calculated as the percentage of the true positive and true negative predictions, $\mathrm{k}$ measures the proportion of all cases that are predicted correctly by a model after accounting for chances on predictions.

\section{RESULTS}

\section{Larval fish community characterization}

We identified 9 species, distributed in 7 different families (Table 1). The most species-rich family was Soleidae ( 2 identified species and 1 non-identified). The 3 most abundant larval species (i.e. D. sargus [ 32\%], S. pilchardus [ 30\%] and P. microps [ 18\%]) comprised $79 \%$ of the total catch. The fish community was dominated by MJ, MS and ER species. In terms of economic importance, 5 of the captured species $(S$. pilchardus, Engraulis encrasicolus, Buglossidium luteum, Solea vulgaris and D. sargus) have commercial value, while 3 (Parablennius gattorugine, Gobius niger and $P$. microps) have recreational value.

ANOSIM analysis results revealed that "season" was the most relevant factor that significantly influences the structure of the fish larvae community in the Guadiana estuary salt marsh area (Table 2). Although not statistically meaningful, the results suggest no significant dissimilarity between summer and winter groups $(\mathrm{R}=0.004 ; \mathrm{p}=0.363)$. Regarding spring and autumn, the results show a statistical meaningful dissimilarity between them $(\mathrm{R}=0.48 ; \mathrm{p}=0.001)$. These findings are represented in the NMDS analysis (Fig. 3). Larval abundance was higher near the mouth of the creek (sta- 
Table 1. - List of fish larvae family and species caught during the study, showing rank by number (based on the individual species abundance); $\mathrm{N}$, total abundance; $\% \mathrm{~N}$, percentage contribution; EG, classifications of ecological guilds (MA, marine adventitious species; MS, marine seasonal migrants; MJ, marine juvenile species; ER, estuarine resident species); EI, species economic importance (R, recreational value; hC, high commercial value; mC, minor commercial value); TO, temporal occurrence (Ja, January; Fb, February; Mr, March; Ap, April; My, May; Jn, June; Jl, July; Sp, September; Oc, October; Nv, November; Dc, December); SO, spatial occurrence (sampling stations 1-7).

\begin{tabular}{|c|c|c|c|c|c|c|c|c|}
\hline Family & Species & Rank & $\mathrm{N}$ & $\% \mathrm{~N}$ & EG & EI & TO & $\mathrm{SO}$ \\
\hline Bleniidae & Parablennius gattorugine & 5 & 6 & 4.62 & MA & $\mathrm{R}$ & My, Jn, Jl & $1,3,5,6$ \\
\hline Clupeidae & Sardina pilchardus & 2 & 39 & 30.00 & MS & $\mathrm{hC}$ & $\mathrm{Ja}, \mathrm{Mr}, \mathrm{Ap}, \mathrm{Oc}, \mathrm{Nv}$ & $5,6,7$ \\
\hline Engraulidae & Engraulis encrasicolus & 4 & 13 & 10.00 & MS & $\mathrm{hC}$ & $\mathrm{Mr}, \mathrm{My}, \mathrm{Jn}, \mathrm{Sp}$ & $3,6,7$ \\
\hline \multirow[t]{2}{*}{ Gobiidae } & Gobius niger & 7 & 1 & 0.77 & ER & $\mathrm{R}$ & $\mathrm{Mr}$ & 1 \\
\hline & Pomatoschistus microps & 3 & 23 & 17.69 & ER & $\mathrm{R}$ & $\mathrm{Fb}, \mathrm{Mr}, \mathrm{Ap}, \mathrm{My}, \mathrm{Jn}, \mathrm{Dc}$ & $1,2,3,4,5,6,7$ \\
\hline \multirow[t]{3}{*}{ Solidae } & Buglossidium luteum & 7 & 1 & 0.77 & MA & $\mathrm{mC}$ & $\mathrm{Mr}$ & 6 \\
\hline & Solea vulgaris & 6 & 2 & 1.54 & MA & $\mathrm{hC}$ & Ap,Jl & 5,6 \\
\hline & n. id. & 7 & 1 & 0.77 & & & $\mathrm{Mr}$ & 6 \\
\hline Sparidae & Diplodus sargus & 1 & 41 & 31.54 & MJ & $\mathrm{mC}$ & Ap, My, Jn & $2,3,4,5,6,7$ \\
\hline Syngnathidae & Syngnathus abaster & 7 & 1 & 0.77 & ER & & My & 5 \\
\hline n. id. & n. id. & 6 & 2 & 1.54 & & & $\mathrm{Mr}$ & 6 \\
\hline
\end{tabular}

Table 2. - ANOSIM analysis of the factor "Season" determined for the fish larvae captured in the Lezíria salt marsh creek from April 2010 to March 2011.

\begin{tabular}{lcc}
\hline Groups & $\mathrm{R}$ & $\mathrm{p}$ \\
\hline Global & 0.187 & 0.001 \\
Spring, Summer & 0.212 & 0.007 \\
Spring, Autumn & 0.480 & 0.001 \\
Spring, Winter & 0.259 & 0.004 \\
Summer, Autumn & 0.147 & 0.038 \\
Summer, Winter & 0.004 & 0.363 \\
Autumn, Winter & 0.069 & 0.044 \\
\hline
\end{tabular}
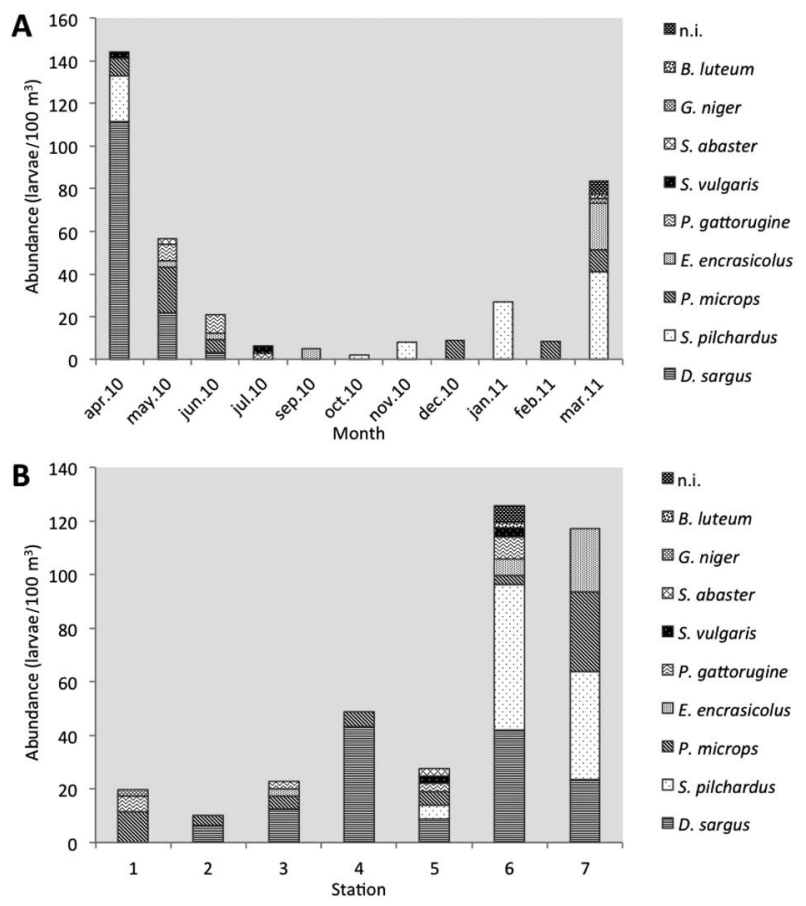

Fig 2. - Temporal (A) and spatial (B) patterns of larval abundance (larvae/100 $\mathrm{m}^{3}$ ) per species captured in the Lezíria salt marsh creek from April 2010 to March 2011.

tions 6 and 7) compared with the more upstream points (stations 1 to 5, Fig. 2B). Peak of abundance occurred in spring, with a maximum value of 144.1 larvae $/ 100 \mathrm{~m}^{3}$ in April followed by 83.7 larvae/100 $\mathrm{m}^{3}$ in March. The lowest values were registered in autumn, with minimum values of 2.0 larvae/100 $\mathrm{m}^{3}$ and 5.1 larvae/100 $\mathrm{m}^{3}$ in October and September (Fig. 2A). The ER $P$. microps has an annual occurrence in the salt marshes, but most of the other species occurred accidently (MA and MS) or during a specific period of the year (MJ that use the salt marsh as a nursery ground).

\section{Environmental factors and their influence on lar- val fish occurrence}

Water temperature was similar at the seven sampled points (Fig. 4B). The average was $19.3^{\circ} \mathrm{C}$, with a minimum of $12.8^{\circ} \mathrm{C}$ in December and a maximum of $27.2^{\circ} \mathrm{C}$ in July (Fig. 4B). Larger differences in salinity were observed between sampled points. The seasonal trend was similar among sampled points but salinity increased towards the main channel of the estuary, i.e. from station 1 to station 7 (Fig. 4A). Inside the creek it ranged from 1.0 in December to 21.1 in July (mean values for stations 1 to 5), and outside the creek from 2.7 in December to 34.5 in March (mean values for stations 6 and 7, Fig. 4A). In December 2010, salinity decreased substantially, coinciding with the great increase in rainfall $\left(430 \mathrm{~mm} \mathrm{day}{ }^{-1}\right)$. High salinity was more pronounced between March and November, when the river flow decreased. The river flow ranged between $55.2 \mathrm{~m}^{3} \mathrm{~s}^{-1}$ in May and $543.05 \mathrm{~m}^{3} \mathrm{~s}^{-1}$ in January (Fig. 5), following a clear seasonal trend with the highest values in winter and the lowest values in summer.

We used the J48 algorithm to induce a prediction model of the suitable environmental conditions for the occurrence of fish larvae. The CCI (\%) and Cohen's kappa statistic of the repeated 10-fold cross-validation

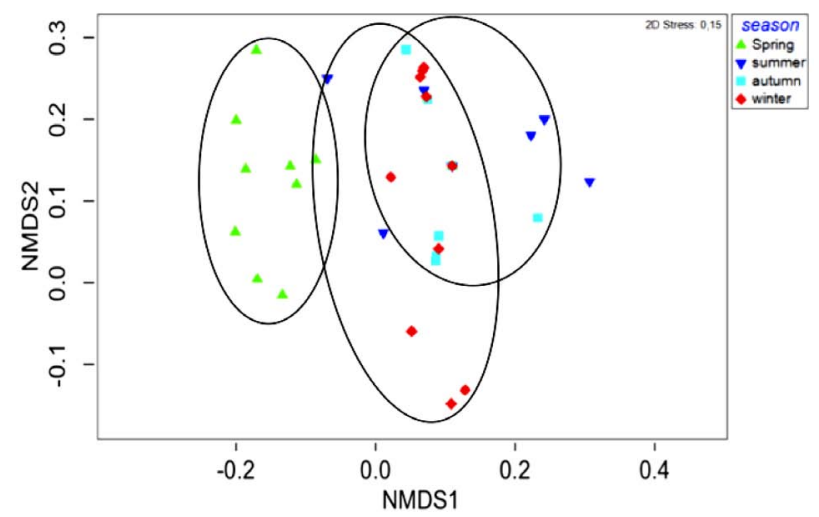

Fig. 3. - Non-parametric multidimensional scaling (NMDS) plots of fish larvae in different season in the Lezíria salt marsh creek. (NMDS) plots based on triangular matrices of Bray-Curtis similarities using species abundance data. 

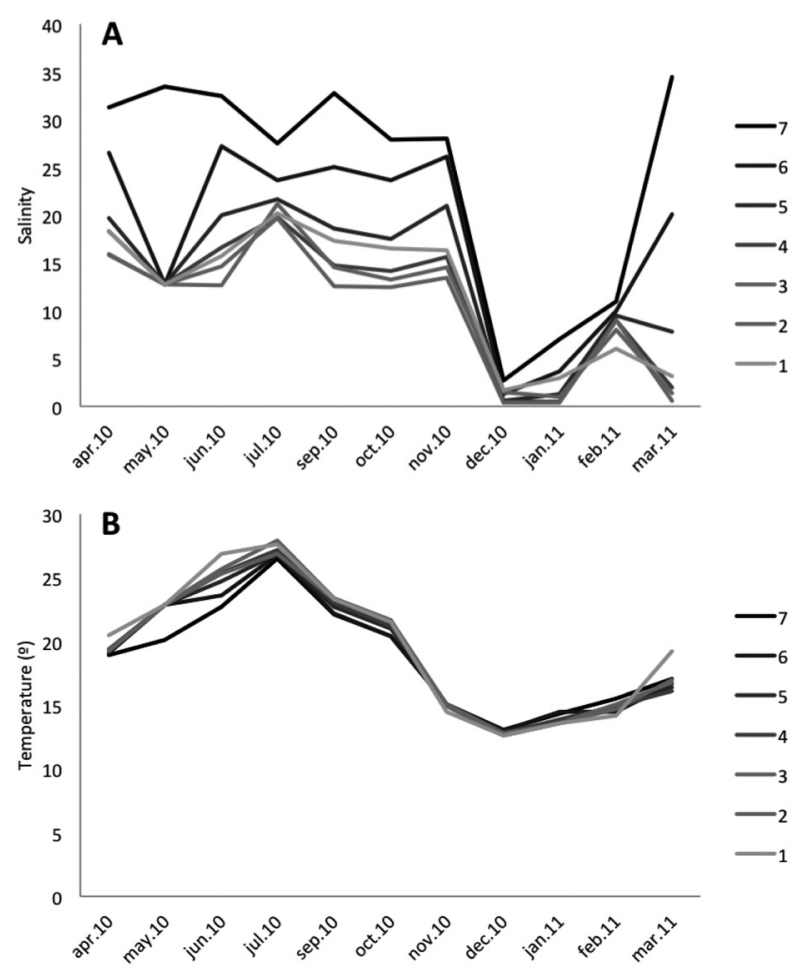

Fig. 4. - Monthly values of the abiotic parameters salinity (A) and temperature (B) per station (lighter (station 1) to darker (station 7) grey scale) in the Castro Marim salt marsh between April 2010 and March 2011.

were $62.3 \%$ and 0.3 . Accordingly, the achieved CCI and $\mathrm{k}$ values indicate agreement for the prediction of fish larvae occurrence (Landis and Koch 1977). The DT was built using the measured 29 attributes (Table 3 ) and the class variable fish larvae. After setting the pruning parameters, i.e. pre-pruning by setting the confidence

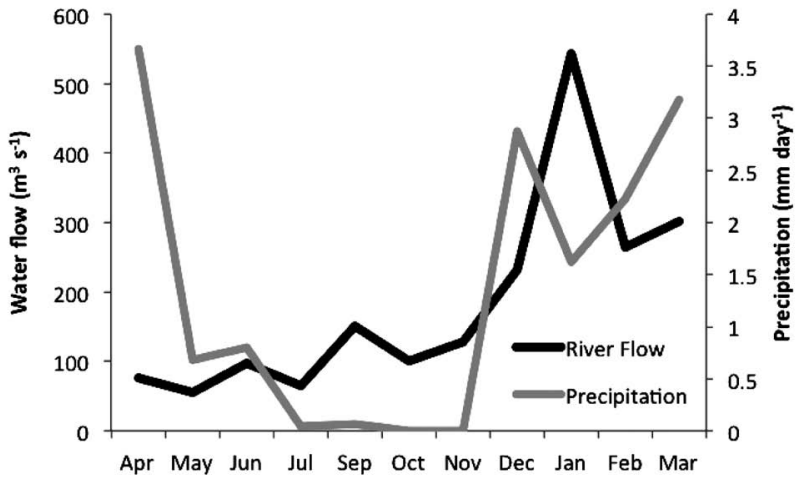

Fig. 5. - Mean weekly and monthly values of river flow and precipitation in the Guadiana River region between April 2010 and March 2011. Source: INAG (2012) (http://snirh.inag.pt/snirh). Data records: Alqueva.

factor to 0.25 and post-pruning by setting the minimal number of examples per leaf to 5 we got the resulting DT that satisfied our criteria (Fig. 6). According to this model, fish eggs, ciliates, precipitation and river flow contained valuable information to predict the occurrence of fish larvae. None of the other tested variables was selected by the algorithm (Fig. 6). The DT showed that larvae abundance is primarily dependent on fish egg abundance; specifically, a low level of larvae occurrence $\leq 2$ larvae $/ 100 \mathrm{~m}^{3}$ ) when the egg abundance is low in combination with a low concentration of ciliates (a potential prey for fish larvae). The model predicted a moderate increase for medium occurrence level (2-10 larvae $/ 100 \mathrm{~m}^{3}$ ) when egg abundance is low, but combined with a high ciliate concentration. The model also forecast a high occurrence of larvae (>10 larvae/100 $\mathrm{m}^{3}$ ) when fish egg abundance is high combined with a precipitation level exceeding $0.8 \mathrm{~mm} \mathrm{day}^{-1}$. During the months with an average rainfall below $0.8 \mathrm{~mm}_{\text {day }}{ }^{-1}$,

Table 3. - Observed abiotic and biotic variables in the Lezíria salt marsh creek, based on 77 samples.

\begin{tabular}{|c|c|c|c|c|c|}
\hline Variable & Unit & Minimum & Maximum & Mean & Standard Deviation \\
\hline 1. Temperature & ${ }^{\circ} \mathrm{C}$ & 12.6 & 27.9 & 19.20 & 4.7 \\
\hline 2. Salinity & _- & 0.35 & 34.50 & 14.32 & 9.26 \\
\hline 3. $\mathrm{NO}_{2}^{-}$ & $\mathrm{mg} \mathrm{L}^{-1}$ & 0.00 & 0.06 & 0.02 & 0.01 \\
\hline 4. $\mathrm{NO}_{3}^{-}$ & $\mathrm{mg} \mathrm{L}^{-1}$ & 0.06 & 4.98 & 1.48 & 1.31 \\
\hline 5. $\mathrm{SiO}_{4}^{4-}$ & $\mathrm{mg} \mathrm{L}^{-1}$ & 0.36 & 9.25 & 3.41 & 2.43 \\
\hline 6. $\mathrm{PO}_{4}^{3-}$ & $\mathrm{mg} \mathrm{L}^{-1}$ & 0.01 & 0.20 & 0.06 & 0.05 \\
\hline 7. $\mathrm{NH}_{4}^{+}$ & $\mathrm{mg} \mathrm{L}^{-1}$ & 0.01 & 0.18 & 0.05 & 0.03 \\
\hline 8. River flow & $\mathrm{m}^{3} \mathrm{~s}^{-1}$ & 55.2 & 543.1 & 182.90 & 139.1 \\
\hline 9. Precipitation & $\mathrm{mm}_{\mathrm{day}}-1$ & 0.00 & 3.66 & 1.38 & 1.34 \\
\hline 10. Distance to main channel & $\mathrm{m}$ & 0.0 & 4574.8 & 2515.40 & 1499.3 \\
\hline 11. Distance to shore & $\mathrm{m}$ & 12.0 & 109.4 & 30.70 & 32.5 \\
\hline 12. Fish eggs & ind. $/ 100 \mathrm{~m}^{3}$ & 0.00 & 2634.75 & 86.72 & 362.32 \\
\hline 13. Total zooplankton & ind. $/ 100 \mathrm{~m}^{3}$ & 0.00 & 340.79 & 10.16 & 40.82 \\
\hline 14. Cladocerans & ind. $/ 100 \mathrm{~m}^{3}$ & 0.00 & 336.18 & 7.33 & 40.17 \\
\hline 15. Siphonophores & ind. $/ 100 \mathrm{~m}^{3}$ & 0.00 & 5.24 & 0.16 & 0.73 \\
\hline 16. Appendicularians & ind. $/ 100 \mathrm{~m}^{3}$ & 0.00 & 31.37 & 0.84 & 4.04 \\
\hline 17. Copepods & ind. $/ 100 \mathrm{~m}^{3}$ & 0.00 & 12.13 & 1.02 & 2.27 \\
\hline 18. Isopods & ind. $/ 100 \mathrm{~m}^{3}$ & 0.00 & 1.36 & 0.17 & 0.30 \\
\hline 19. Gastropods & ind. $/ 100 \mathrm{~m}^{3}$ & 0.00 & 5.14 & 0.35 & 1.00 \\
\hline 20. Decapods & ind. $/ 100 \mathrm{~m}^{3}$ & 0.00 & 1.96 & 0.24 & 0.42 \\
\hline 21. Chaetognaths & ind. $/ 100 \mathrm{~m}^{3}$ & 0.00 & 0.41 & 0.03 & 0.06 \\
\hline 22. Polichaetes & ind. $/ 100 \mathrm{~m}^{3}$ & 0.00 & 0.30 & 0.02 & 0.05 \\
\hline 23. Hidromedusae & ind. $/ 100 \mathrm{~m}^{3}$ & 0.00 & 259.74 & 7.93 & 36.80 \\
\hline 24. Ciliates & cel. L ${ }^{-1}$ & 0.00 & 59377.60 & 7245.10 & 10673.10 \\
\hline 25. Chlorophyll $a$ & $\mu \mathrm{g} \mathrm{L}^{-1}$ & 1.30 & 19.28 & 6.31 & 2.95 \\
\hline 26. Total phytoplankton & cel. L $L^{-1}$ & 16449.2 & 303507.80 & 80953.80 & 64776.60 \\
\hline 27. Dinophycae & cel. $L^{-1}$ & 0.00 & 152255.40 & 13685.10 & 24128.60 \\
\hline 28. Bacilariophycae & cel. $L^{-1}$ & 7823.4 & 281441.80 & 77692.10 & 55869.00 \\
\hline 29. Chlorophycae & cel. $L^{-1}$ & 0.00 & 264390.80 & 9477.70 & 30450.70 \\
\hline
\end{tabular}




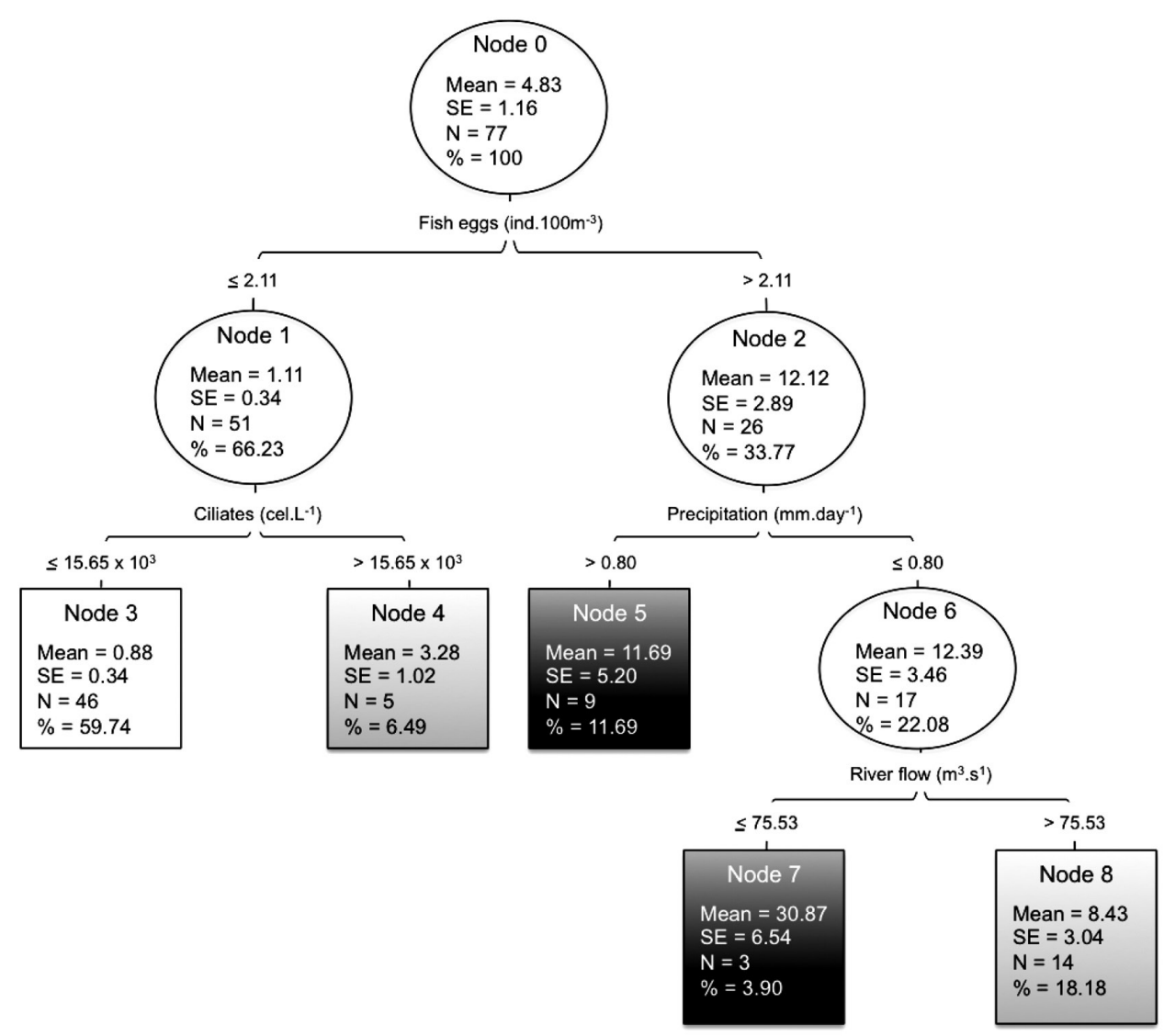

Fig. 6. - Single-target DT predicting the abundance of fish larvae along the Lezíria salt marsh creek. Each node indicates mean and standard error (se) of larvae abundance (ind. $\left./ 100 \mathrm{~m}^{3}\right)$; total number of larvae per node $(\mathrm{N})$ and percentage of larvae per node $(\%)$. Squares represent final nodes with larvae abundance predictions. In grey scale: white for low abundance $\left(\leq 2\right.$ larvae/100 $\left.\mathrm{m}^{3}\right)$, light grey for medium abundance (2-10 larvae/100 $\left.\mathrm{m}^{3}\right)$, and dark grey for high abundance $\left(>10\right.$ larvae/100 $\left.\mathrm{m}^{3}\right)$.

a high abundance of fish larvae is expected only when river flow rate does not exceed $75.53 \mathrm{~m}^{3} \mathrm{~s}^{-1}$; otherwise larvae abundance drops to medium level (Fig. 6).

\section{DISCUSSION}

The present study is the first to investigate the larval fish community in the Guadiana salt marsh area and the influence of environmental parameters on its occurrence through a DT model. The model discloses the EF3 rule, i.e. eggs, food availability, flooding events and river flow as the main players in determining favourable conditions for larval fish occurrence in the lower marshes of the Guadiana estuary.

Despite the higher abundance of the three species (D. sargus, $S$. pilchardus and $P$. microps), we found lower diversity and abundance of the overall fish larvae community compared with previous surveys carried out in adjacent areas of the Guadiana estuary (Chícharo et al. 2000 and Faria et al. 2006). However, in these studies, captures exclusively near our sampling area had diversity and abundance values much closer to our observations. Chícharo et al. (2000) reported for the sampling point "Carrasqueira creek" (a marsh creek a few meters from our sampling site) the presence of 5 different species and an abundance peak of 143 larvae/100 $\mathrm{m}^{3}$ in March 2000. Values observed by Faria et al. (2006) for the lower estuary were slightly higher, with 19 different species and a maximum abundance of 285 larvae/100 $\mathrm{m}^{3}$ in June 2002. Diversity in the salt marsh creek agreed well with descriptions in the literature for other European marshes, where few species were found. Koutsogiannopoulou and Wilson (2007) observed 10 species over two years in Dublin Bay, Ireland, while Green et al. (2009) reported 14 species over one year on the Essex coastline, United Kingdom. An exception is Laffaille et al. (2000), who recorded 31 species in Mont Saint Michel Bay, France, but over a longer sampling period (three years). Abundance comparisons are harder, because abundance is expressed in different units and total abundances reflect values of different sampling designs and different sampling periods using dissimilar sampling gears. Yet, looking at total abundances normalized for a one-year period, capture values are significantly higher than ours. Koutsogiannopoulou and Wilson (2007) captured 3275 individuals, Green et al. (2009) 2821 individuals and Laffaille et al. (2000) 83333 individuals. These surveys exclusively aimed to capture juveniles and not larvae, as in the present study. Only Green et al. (2009) attempted capture of larvae and juveniles simultaneously, but they were present in short seasonal peaks.

Among ER, MJ, MS and MA, all the 9 identified species were reported in the lower estuary zones of Guadiana by Chícharo et al. (2000) and Faria et al. (2006). In addition, larval fish community composition 
in the salt marsh creek is comparable that reported by Veiga et al. (2006). Only three of the identified larvae species (S. vulgaris, B. luteum and Syngnathus abaster) were not reported by Veiga et al. (2006), suggesting that the salt marsh is mainly used during the early life cycle of these species. The larval fish assemblage composition differed from other European marshes in France (Laffaille et al. 2000), Ireland (Koutsogiannopoulou and Wilson 2007), and the United Kingdom (Green et al. 2009). However, the ER Pomatoschistus sp. was reported among the two most abundant species in all studies.

The occurrence of the MJ D. sargus as the dominant species is not surprising, because Sparidae is one of the most common families in estuaries and salt marsh assemblages worldwide (e.g. Gonçalves and Beldade 2000, Hindell and Jenkins 2004). Diplodus sargus spawn in coastal areas and after that eggs and larvae disperse at the scale of 100-200 km forced by marine currents, reaching nursery habitats such as estuaries (Franco et al. 2012). Also, the occurrence of the larvae of the MS S. pilchardus in the lower estuary is more related to oceanic circulation and water advection effects than to active habitat selection, i.e. the adults spawn in coastal zones and subsequently the eggs and larvae are transported from coastal into estuary zones by tidal current forces (Faria et al. 2006). The high occurrence of the ER P. microps is also not surprising, because it depends on estuarine habitats for its entire lifecycle. Furthermore, it is one of the most common species in estuaries and lagoons and along the shores in Europe (Laffaille et al. 2000, Koutsogiannopoulou and Wilson 2007, Green et al. 2009). While larval dispersal of ERs depends exclusively on the biology of the species (e.g. hatching date, pelagic larval duration and larval swimming behaviour), larval dispersal of MJs and MSs also depends on the local oceanographic features (e.g. directional currents).

There was no evidence of higher larvae occurrence inside the salt marsh creek than outside. A trend of higher abundances near the mouth of the creek than in more interior zones was evident (Fig. 2B). Larval fish did not exhibit a preference for vegetated habitats over sand bottoms in laboratory experiments (Gonçalves et al. 2012), a finding which corroborates these field observations. The relative contribution of the creek to the local population was estimated as $33 \%$ (number of larvae inside the creek [stations 1 to 5] / total number of larvae), slightly lower than the $51 \%$ estimated by Chícharo et al. (2000).

Several studies have reported that intertidal creeks provide important habitat for fishes (Hampel et al. 2003, Jin et al. 2007), but juveniles and adults generally dominate catches. Fishes at a more developed stage, with a higher swimming capacity, can more easily access tidal creeks and marsh habitats and remain there. It is only near settlement that fish larvae of many species become capable of swimming faster than the mean ambient current (Leis 2006). Particularly in the lower Guadiana estuary, strong currents are produced on the ebb (Garel et al. 2009), the period of our samplings. We assume that we failed to capture more larvae because the tidal current may have carried part of them out of the creek. We also accept that capture efforts have targeted smaller fishes than the ones that more regularly use salt marsh areas. Further surveys on this particular area should tests other fishing gears, such as seine nets, fixed traps and water pumps and target advanced larval phases or juvenile fish.

The ANOSIM indicated that winter and summer groups are more similar to each other, while autumn and spring groups are more dissimilar in terms of abundance and species composition. The similarity between summer and winter groups was mainly explained by species abundance $\left(27.4\right.$ and 36.5 larvae/100 $\mathrm{m}^{3}$ ) rather than species composition (5 species observed in summer, 2 in winter, and only D. sargus was common to the two groups), while abundance (15.4 and 285.7 larvae/100 $\mathrm{m}^{3}$ ) and species composition (2 species observed in autumn and 9 in spring) both contributed to the differences between the autumn and spring groups.

The short period of our study (one year) limits conclusions about the seasonal changes on the community structure in the Guadiana estuary, but our results are correlated with the in situ observations performed by others in different years (Chícharo et al. 2000, Faria et al. 2006, Veiga et al. 2006). Overall, biodiversity in the salt marsh creek was relatively constant throughout the year, being dominated by the MJ D. sargus in spring, the MS S. pilchardus in autumn and winter, and the ER P. microps all the year. Peaks of total abundance were recorded during spring months, as observed by Chícharo et al. (2000), Faria et al. (2006) and Veiga et al. (2006). Abundance maxima in marsh areas further north in Europe were recorded later during the early autumn (Laffaille et al. 2000, Koutsogiannopoulou and Wilson 2007, Green et al. 2009). The highest abundance levels are coincident with periods of high zooplankton productivity along the Portuguese coast (Chícharo et al. 2006). The rapid decline observed in July seems to be more related to the spawning periods of fish species coinciding with an increase in predatory jellyfish abundance (Muha et al. 2012) rather than to the lack of zooplankton, which is still abundant during this month.

Periods of high fish eggs abundance typically overlap with peaks of larvae occurrence, especially for fishes with short hatching periods. However, the DT revealed that the peaks of fish eggs by themselves do not guarantee a high occurrence of fish larvae. This may be related to other factors, such as temperature and predation, which are the main causes of mortality in fish eggs (Riveiro et al. 2004).

The DT model also indicates that an increased density of potential prey might compensate for the low density of fish eggs. Among all potential prey, ciliates were the only ones that showed a positive correlation with the density of fish larvae. In general, marine fish larvae feed on copepods, but, they can consume other prey such as cladocerans, molluscs and ciliates (Chícharo et al. 2012). Looking at feeding preferences of the marine dominant species, only the MS S. pilchardus has been reported to feed on ciliates. According to Morote et al. (2010), S. pilchardus larvae $<10 \mathrm{~mm}$ standard length feed mainly on the tintinnid Codonel- 
lopsis sp. and copepod nauplii with the ciliate Codonellopsis sp., accounting for $48 \%$ of their diet. Tintinnids were also the major prey items in the gut contents of S. pilchardus larvae collected off southern Portugal (Chícharo 1998). Sanchez-Velasco and Norbis (1997) reported that copepod nauplii, calanoid copepod eggs and cladoceran species were the dominant prey of the MJ D. sargus ranging between 2 to $7 \mathrm{~mm}$ total lengths. The ER P. microps is described as an opportunistic feeder that selects prey that are in sufficient quantities and are easily available within ecosystems (Antholz et al. 1991). Smaller P. microps analysed for gut contents were $35 \mathrm{~mm}$ average standard length (Mendonça et al. 2009); among the digested species, amphipods, harpacticoids, polychaetes, chironomids (larvae and pupae), and bivalve syphons. Based on the diet of these species, it is unlikely that $D$. sargus and $P$. microps contributed to the positive correlation between ciliates and larvae occurrence in the Guadiana estuary. The MS $S$. pilchardus seems to be the major beneficiary of the high abundances of ciliates observed in the study area.

The DT model explores associations between the density of fish larvae and the abiotic factors precipitation and river flow. Our findings corroborate the results of other studies, in which a positive correlation of rainfall and abundance of fishes was evident (Salen-Picard et al. 2002 and Whitfield et al. 2005). These associations might be due to other variables, including primary or secondary production that results from terrestrial nutrient addition (Meynecke et al. 2006). Salen-Pilcard et al. (2002) suggested that an increase in prey density after flooding events favoured different stages of the Solea solea life cycle, enhancing its population size for several years. Also, the model suggests that months with low precipitation combined with high-flow periods reduce the number of larval fish. Eggs and larvae appear to be flushed out as a result of the excessive amount of river flow that will potentially contribute to the loss of larvae from the estuary into the marine environment. Moderate freshwater discharge increases the overall primary production of estuarine systems that are vital for the nursery function of the lower reaches of estuaries (Dolbeth et al. 2008) and promotes the emergence of chemical cues used by larvae for orientation in estuarine zones (Costa et al. 2007). However, excessive supply can effectively alter the larval composition of estuarine resident and estuarine dependent marine fish species (Strydom et al. 2002). In terms of environmental factors that influence the occurrence of fish larvae, flooding events and river flow are particularly important, suggesting that the recruitment success and maintenance of fish diversity will require good water management that takes into account natural hydrography. It is important to maintain sufficient water flow during dry seasons to ensure the input of nutrients to the lower zones of the estuary, but a sudden increase in river flow must be avoided to prevent the advection of fish larvae out of the system.

Overall, this work indicated that, although the most common species use this habitat during their early stages of development, the density of fish larvae in the salt marsh zone of the Guadiana estuary is lower than in adjacent areas. This study resolves the influence of environmental factors on fish larvae density and the temporal and spatial occurrence of larvae in salt marsh habitats. The results highlight the value of restoration and conservation of salt marsh habitats, and emphasize the importance of flow-rate control in dry seasons that should be performed in parallel with fishery activities in the Guadiana region.

\section{ACKNOWLEDGEMENTS}

The authors are indebted to Joana Cruz and David Piló, who helped with the field work. This work was supported by the FCT (Portuguese Foundation for Science and Technology) through a $\mathrm{PhD}$ grant awarded to Renata Gonçalves (SFRH/BD/47985/2008). We are also grateful to the anonymous reviewers who greatly improved earlier drafts of this manuscript.

\section{REFERENCES}

Antholz B., Meyer-Antholz W., Zander C.D. 1991. Feeding activities of two euryhaline small-sized fish in a western Baltic brackish fjord. Helgolander Meeresun. 45: 287-300. http://dx.doi.org/10.1007/BF02365521

Baltz D.M., Chet Rakocinski C., Fleeger J. 1993. Microhabitat use by marsh-edge fishes in a Louisiana estuary. Environ. Biol. Fish. 36: 109-126. http://dx.doi.org/10.1007/BF00002790

Beja P., Rosa S., Porto M., et al. 2007. Plano de Ordenamento da Reserva Natural do Sapal de Castro Marim e Vila Real de Santo António da Mata de Monte Gordo e dos Sapais de Beliche-Caroucha. ERENA - Ordenamento e Gestão de Recursos Naturais, Lda. $28 \mathrm{pp}$.

Chícharo M.A. 1998. Nutritional condition and starvation in Sardina pilchardus (L.) larvae off Southern Portugal compared with some environmental factors. J. Exp. Mar. Biol. Ecol. 225: $123-137$.

http://dx.doi.org/10.1016/S0022-0981(97)00212-8

Chícharo L., Chícharo M.A., Amaral A., et al. 2000. Valorização dos recursos pesqueiros do estuaário do Guadiana. Relatório Final do Projecto. Acção de Valorização do Baixo Guadiana. ODIANA, $111 \mathrm{pp}$.

Chícharo L., Chícharo M.A., Ben-Hamadou R. 2006. Use of a hydrotechnical infrastructure (Alqueva dam) to regulate planktonic assemblages in the Guadiana estuary: basis for sustainable water and ecosystem services management. Est. Coast. Shelf. Sci. 70 (1-2): 3-18. http://dx.doi.org/10.1016/j.ecss.2006.05.039

Chícharo M.A., Leitão T., Range P., et al. 2009. Alien species in the Guadiana Estuary (SE-Portugal/SW-Spain): Blackfordia virginica (Cnidaria, Hydrozoa) and Palaemon macrodactylus (Crustacea, Decapoda): potential impacts and mitigation measures. Aquat. Inv. 4(3): 501-506. http://dx.doi.org/10.3391/ai.2009.4.3.11

Chícharo M.A., Amaral A., Faria A., et al. 2012. Are tidal lagoons ecologically relevant to larval recruitment of small pelagic fish? An approach using nutritional condition and growth rate. Est. Coast. Shelf. Sci. 112: 265-279 http://dx.doi.org/10.1016/j.ecss.2012.07.033

Clarke K.R., Warwick R.M. 2001. Changes in Marine Communities: An Approach to Statistical Analysis and Interpretation, second ed. Primer-e, Plymouth, UK, $160 \mathrm{pp}$.

Costa M.J., Vasconcelos R., Costa J.L., et al. 2007. River flow influence on the fish community of the Tagus estuary (Portugal). Hydrobiologia. 587: 113-123. http://dx.doi.org/10.1007/s10750-007-0690-x

Craig J.K., Crowder L.B. 2000. Factors influencing habitat selection in fishes with a review of marsh ecosystems. pp. 241- 265 In: Weinstein M.P. and Kreeger D.A. (eds), Concepts and Controversies in Tidal Marsh Ecology. Kluwer Academic Publishers, Dordrecht, $875 \mathrm{pp}$.

Dolbeth M., Martinho F., Viegas I., et al. 2008. Estuarine production of resident and nursery fish species: Conditioning by drought events? Est. Coast. Shelf. Sci. 78: 51-60. 
http://dx.doi.org/10.1016/j.ecss.2007.11.021

Faria A., Morais P., Chícharo M.A. 2006. Ichthyoplankton dynamics in the Guadiana estuary and adjacent coastal area, SouthEast Portugal. Est. Coast. Shelf. Sci. 70: 85-97. http://dx doi.org/10.1016/j ecss. 2006.05.032

França S., Costa M.J., Cabral H.N. 2009. Assessing habitat specific fish assemblages in estuaries along the Portuguese coast. Est. Coast. Shelf. Sci. 83: 1-12. http://dx.doi.org/10.1016/j.ecss.2009.03.013

Franco A. Gillanders M., Benedetto G., et al. 2012. Dispersal patterns of coastal fish: implications for designing networks of marine protected areas. PLoS ONE. 7(2):e31681. http://dx.doi.org/10.1371/journal.pone.0031681

Franco-Gordo C., Godınez-Dominguez E., Suarez-Morales E. 2002. Larval fish assemblages in waters off the central Pacific coast of Mexico. J. Plankton Res. 24: 775-784. http://dx.doi.org/10.1093/plankt/24.8.775

Garel E., Pinto L., Santos A., et al. 2009. Tidal and river discharge forcing upon water and sediment circulation at a rock-bound estuary (Guadiana estuary, Portugal). Est. Coast. Shelf. Sci. 84(2): 269-281. http://dx.doi.org/10.1016/j.ecss.2009.07.002

Gonçalves E., Beldade R. 2000. Avaliação do Estado de Conhecimento e Inventariação das Comunidades Ictiológicas da Reserva Natural do Sapal de Castro Marim e Vila Real de Santo António. Relatório Final-ISPA, ICN, RNSCMVRSA, Lisboa, 26 pp.

Gonçalves R., Ben-Hamadou R., Chícharo L. 2012. Selection of coastal estuarine habitats by Atherina boyeri larvae in laboratory experiments. Ecohydrol. Hydrobiol. 12(4): 321-326. http://dx.doi.org/10.2478/v10104-012-0023-1

Grasshoff K., Ehrhardt M., Kremling K. 1983. Methods of Seawater Analysis. Second ed. Verlag Chemie, Kiel, 419 pp.

Green B., Smith D., Earley S., et al. 2009. Seasonal changes in community composition and trophic structure of fish populations of five salt marshes along the Essex coastline, United Kingdom. Est. Coast. Shelf. Sci. 85: 247-256. http://dx.doi.org/10.1016/j.ecss.2009.08.008

Hampel H., Cttrijijsse M., Vincx M. 2003. Tidal, diel and semilunar changes in the faunal assemblage of an intertidal salt marsh creek. Est. Coast. Shelf. Sci. 56: 795-805. http://dx.doi.org/10.1016/S0272-7714(02)00296-2

Hettler W. 1989. Nekton use of regularly-flooded salt marsh cordgrass habitat in North Carolina, USA. Mar. Ecol. Prog. Ser. 56: 111-118. http://dx.doi.org/10.3354/meps056111

Hindell J.S., Jenkins G.P. 2004. Spatial and temporal variability in the assemblage structure of fishes associated with mangroves (Avicennia marina) and intertidal mudflats in temperate Australian . Mar. Biol. 144: 385-395. http://dx.doi.org/10.1007/s00227-003-1201-x

Jin B., Fu C., Zhong J., et al. 2007. Fish utilization of a salt marsh intertidal creek in the Yangtze River estuary, China. Est. Coast. Shelf. Sci. 73: 844-852. http://dx.doi.org/10.1016/j.ecss.2007.03.025

Knap A.H., Michaels A.T., Close A., et al. (eds). 1996. Protocol for the Joint Global Ocean Flux Study (JGOFS) Core measurements, JGOFS Report No. 19, Reprint of the IOC Manuals and Guides No. 29. 170 pp.

Kneib R.T. 1997. Early life stages of resident nekton in intertidal marshes. Estuaries. 20: 214-230. http://dx.doi.org/10.2307/1352732

Koutsogiannopoulou V., Wilson J. 2007. The fish assemblage of the intertidal salt marsh creeks in North Bull Island, Dublin Bay: seasonal and tidal changes in composition, distribution and abundance. Hydrobiologia. 588: 213-224. http://dx.doi.org/10.1007/s10750-007-0664-Z

Kramer D.L., Rangeley R.W., Chapman L.J. 1997. Habitat selection: patterns of spatial distribution from behavioural decisions. In: Godin J.J. (ed.), Behavioural ecology of teleost fishes. Oxford University Press, New York, NY, USA, pp 37-80.

Laffaille P., Feunteun E., Lefeuvre J.C. 2000. Composition of Fish Communities in a European Macrotidal Salt Marsh (the Mont Saint-Michel Bay, France). Est. Coast. Shelf. Sci. 51(4): 429-438. http://dx.doi.org/10.1006/ecss.2000.0675

Landis J.R., Koch G.G. 1977. The measurement of observer agreement for categorical data. Biometrics. 33: 159-174. http://dx.doi.org/10.2307/2529310

Leis J.M. 2006. Are larvae of demersal fishes plankton or nekton? Adv. Mar. Biol. 51: 57-141.
http://dx.doi.org/10.1016/S0065-2881(06)51002-8

Mathieson S., Cattrijsse A., Costa M.J., et al. 2000. Fish assemblages of European tidal marshes, a comparison based on species, families and functional guilds. Mar. Ecol. Prog. Ser. 204: 225-242.

http://dx.doi.org/10.3354/meps204225

Mendonça V.M., Raffaelli D.G., Boyle P.R., et al. 2009. Trophodynamics in a Shallow Lagoon off Northwestern Europe (Culbin Sands, Moray Firth): Spatial and Temporal Variability of Epibenthic Communities, Their Diets, and Consumption Efficiency. Zool. Stud. 48(2): 196-214.

Meynecke J., Lee S.Y., Duke N.C., et al. 2006. Effect of rainfall as a component of climate change on estuarine fish production in Queensland, Australia. Est. Coast. Shelf. Sci. 69: 491-504. http://dx.doi.org/10.1016/j.ecss.2006.05.011

Morais P., Chícharo M.A., Chícharo L. 2009. Changes in a temperate estuary during the filling of the biggest European dam. Sci. Total Environ. 407: 2245-2259. http://dx.doi.org/10.1016/j.scitotenv.2008.11.037

Morote E., Olivar M.P., Villate F., et al. 2010. A comparison of anchovy (Engraulis encrasicolus) and sardine (Sardina pilchardus) larvae feeding in Northwest Mediterranean: influence of prey availability and ontogeny. ICES J. Mar. Sci. 67: 897-908. http://dx.doi.org/10.1093/icesjms/fsp302

Muha T.P., Chícharo L., Morais P., et al. 2012. The effect of distinct hydrologic condition on the zooplankton community in an estuary under Mediterranean climate influence. Ecohydrol. Hydrobiol. 12(4): 327-335. http://dx.doi.org/10.2478/v10104-012-0027-x

Pereira R., Teodódio M.A., Garrido S. 2014. An experimental study of Aurelia aurita feeding behavior: inference of the potential predation impact on a temperate estuarine nursery area. Est. Coast. Shelf. Sci. 146: 102-110. http://dx.doi.org/10.1016/j.ecss.2014.05.026

Quinlan J.R. 1993. C4. 5: programs for machine learning. Morgan Kaufmann Publishers Inc. San Francisco CA, USA, 302 pp.

Quinn G.P., Keough M.J. 2002. Experimental Design and Data Analysis for Biologists. Cambridge University Press, Edinburgh, UK, 553 pp. http://dx.doi.org/10.1017/CBO9780511806384

Ré P. 1999. Ictioplâncton estuarino da Península Ibérica (Guia de identificação dos ovos e estados larvares planctónicos). Câmara Municipal de Cascais, Cascais, 163 pp.

Riveiro I., Guisande C., Maneiro I., et al. 2004. Parental effects in the European sardine Sardina pilchardus. Mar. Ecol. Prog. Ser. 274: 225-234.

http://dx.doi.org/10.3354/meps274225

Rountree R.A., Able K.W. 1996. Seasonal abundance, growth, and foraging habitats of juvenile smooth dogfish, Mustelus canis, in a New Jersey estuary. Fish. Bull. 94: 522-534.

Russell F.S. 1976. The eggs and planktonic stages of British marine fishes. Academic Press, NY, USA, $524 \mathrm{pp}$.

Salen-Picard C., Darnaude A.M., Arlhac A.M., et al. 2002. Fluctuations of macrobenthic populations: a link between climatedriven river run-off and sole fishery yields in the Gulf of Lions. Oecologia 133: 380-388. http://dx.doi.org/10.1007/s00442-002-1032-3

Sanchez-Velasco L., Norbis W. 1997. Comparative diets and feeding habits of Boops boops and Diplodus sargus larvae, two sparid fishes co-occurring in the Northwestern Mediterranean (May 1992). Bull. Mar. Sci. 61(3): 821-835.

Strydom N., Whitfield A., Paterson A. 2002. Influence of altered freshwater flow regimes on abundance of larval and juvenile Gilchristella aestuaria (Pisces: Clupeidae) in upper reaches of two South African estuaries. Mar. Freshw. Res. 53: 431-438. http://dx.doi.org/10.1071/MF01077

Veiga P., Vieira L., Bexiga C., et al. 2006. Structure and temporal variations of fish assemblages of the Castro Marim salt marsh, southern Portugal. Est. Coast. Shelf. Sci. 70: 27-38. http://dx.doi.org/10.1016/j.ecss.2006.05.037

Videira N., Antunes P., Santos R. 2008. Scoping river basin management issues with participatory modeling: The Baixo Guadiana experience. Ecol. Econ. 68: 965-978. http://dx.doi.org/10.1016/j.ecolecon.2008.11.008

Whitfield A.K., 2005. Fishes and freshwater in southern African estuaries e a review. Aquat. Living Resour. 18: 275-289. http://dx.doi.org/10.1051/alr:2005032

Witten I.H., Frank E., Hall M.A. 2011. Data mining: Practical machine learning tools and techniques, Morgan Kaufmann Publishers. Burlington, MA, USA, 664 pp. 